\title{
Impact of Heat Damaged Corn Gluten Meal as Fertilizer on Forage Production During Winter and Summer Seasons and Soil Characteristics
}

\author{
K. J. $\operatorname{Han}^{1} \&$ W. D. Pitman ${ }^{2}$ \\ ${ }^{1}$ School of Plant, Environmental, and Soil Sciences, Louisiana State University Agricultural Center, Baton \\ Rouge, Louisiana, USA \\ ${ }^{2}$ Hill Farm Research Station, Louisiana State University Agricultural Center, Homer, Louisiana, USA \\ Correspondence: K. J. Han, 219 M. B. Sturgis Hall, School of Plant, Environmental, and Soil Sciences, \\ Louisiana State University Agricultural Center, Baton Rouge, Louisiana 70803, USA. Tel: 1-225-578-1305. \\ E-mail: kjhan@agcenter.lsu.edu
}

Received: December 2, 2019

Accepted: January 14, 2020

Online Published: February 15, 2020

doi:10.5539/jas.v12n3p67

URL: https://doi.org/10.5539/jas.v12n3p67

\begin{abstract}
Corn gluten meal (CGM) has been used as a supplement for livestock feeding due to its high concentration of digestible nitrogen (N) compounds. Heat damaged CGM (HDCGM), which is not suitable for livestock feeding, may still have value as an organic fertilizer. Objective of the study was to evaluate the impacts of non-feed grade HDCGM on forage production from annual cool and warm season grasses and soil characteristics. Pre-plant incorporated HDCGM at $3 \mathrm{Mg} / \mathrm{ha}$ was compared with $4.2 \mathrm{Mg} / \mathrm{ha}$ poultry litter (POTL), and $160 \mathrm{~kg} / \mathrm{ha}$ commercial $\mathrm{N}$ fertilizer (COMF), and zero fertilizer (ZERO) for production of the cool-season 'Prine' annual ryegrass (Lolium multiflorum), and the warm-season 'Greentreat' sorghum $\times$ sudangrass (SS) hybrid (Sorghum bicolor). The treatments were repeated at the same site on December 3, 2010 (planted annual ryegrass), May 26, 2011 (planted SS hybrid), October 24, 2011 (planted annual ryegrass) and May 18, 2012 (planted SS hybrid). The HDCGM had 68\% more $\mathrm{N}$ concentration than POTL, while its $\mathrm{P}, \mathrm{K}, \mathrm{Mg}$, and Ca were less than half in POTL. The residual N concentration in buried HDCGM and POTL increased in a similar pattern with time in soil. The HDCGM produced less dry matter (DM) of annual ryegrass and SS hybrid than POTL; however, the differences between the two treatments were not statistically significant. All treatments produced more DM in the second than first year. After two years of field test, soil receiving HDCGM contained higher soil organic matter $(\mathrm{OM})$ and $\mathrm{N}$ than receiving POTL. Although not as beneficial as POTL for DM production, HDCGM showed potential value as a slow release fertilizer to improve DM production and soil characteristics.
\end{abstract}

Keywords: heat damaged corn gluten meal, organic fertilizer, poultry litter, forage crop, organic soil amendment

\section{Introduction}

Continued cultivation of annual forage crops for hay or silage can reduce soil OM and N, and eventually reduce productivity of the land. Approaches to directly supply soil OM through application of organic soil amendments such as poultry litter, which can also provide plant nutrients, have been often used to maintain soil productivity and boost crop production. Poultry litter (POTL) has been used as an alternative to commercial fertilizer, both to recycle a waste material and to provide an economical source of slow release plant nutrients.

Corn gluten meal (CGM) containing around 80 g nitrogen $(\mathrm{N})$ per $\mathrm{kg}$ DM has conventionally been used as a protein supplement for livestock. The CGM, a byproduct produced during corn grain processing, has become an alternative to soybean (Glycine max (L.) Merr.) meal in livestock feeding. Extraction of starch and oil from the corn (Zea mays L.) grain results in the byproduct (CGM) containing a high concentration of N. Although there is variation, the average concentration of $\mathrm{N}$ is near $112 \mathrm{~g} / \mathrm{kg} \mathrm{DM}$ in CGM (Wu, 2001), which is higher than in poultry litter. Moreover, degradability of $\mathrm{N}$ in CGM is moderately high in the rumen of cattle (Firkins, Berger, Fahey, \& Merchen, 1984; Titgemeyer, Merchen, \& Berger, 1989), indicating timely degradation potential of CGM in soil for release of available $\mathrm{N}$ to forage crops when applied as a soil amendment.

Byproducts often receive less consideration than justified by their economic value, and some CGM has been improperly stored under certain circumstances. When CGM with high moisture is stored in bulk, extensive 
bacterial oxidation of residual carbohydrate and protein may occur resulting in excessive heat accumulation. This condition produces an interrelated biochemical reaction resulting in an increased proportion of highly bound $\mathrm{N}$, chemically identifiable as acid detergent insoluble nitrogen (ADIN) in feed materials (Van Soest \& Mason, 1991). Thus increased concentrations of heat-damaged $\mathrm{N}$ can occur in CGM under improper storage conditions.

Since CGM utilization has been mostly focused on either as a nutritional supplement or pre-emergent herbicidal treatment, information regarding benefit of CGM as fertilizer to increase DM production and improve soil characteristics is scarce. Although not suitable for use as livestock feed, HDCGM still contains a high concentration of $\mathrm{N}$ and may be an effective alternative fertilizer with slow $\mathrm{N}$ release potential. This study was conducted to evaluate the fertilizer value of non-feed grade CGM, termed as heat damaged CGM (HDCGM), on annual DM production and soil characteristics.

\section{Method}

\subsection{Fertilizer Treatments and Forage Crop Planting}

A field plot experiment was conducted to evaluate the fertilizer value of HDCGM in comparison with POTL, a commercial fertilizer (COMF), and an unfertilized control (ZERO) at the Louisiana State University (LSU) Agricultural Center (AgCenter) Southeast Research Station at Franklinton, LA, USA. Soil at the site is a Tangi silt loam (fine-silty, mixed thermic Typic Fragiudult). The HDCGM was donated by Natural Resources Recovery Inc. (Baton Rouge, LA). Poultry litter (POTL) was collected from a broiler house at the LSU AgCenter Hill Farm Research Station. The treatments were arranged in a randomized complete block design with four replications. Plots were 1.5 by $7.6 \mathrm{~m}$ with six rows at $20-\mathrm{cm}$ row spacing. Seedbeds were prepared using a BHT55 rotary tiller (Bush $\operatorname{Hog}^{\circledR}$ Selma, AL) with the treatments incorporated during seedbed preparation. Soil was subsequently packed using a roller. A small-plot drill planter (Kincaid Equipment Manufacturing, Haven, KS) was used to plant the grasses.

The amount of $\mathrm{N}$ applied in the HDCGM, POTL and COMF to each cool-season and warm-season annual forage crop was fixed at $160 \mathrm{~kg} / \mathrm{ha}$, which is an upper limit for $\mathrm{N}$ rate in a single application for the annual grasses (Eichhorn Jr., Redfearn, \& Venuto, 2000). Since the P and K concentrations in HDCGM and POTL differed, treatments were balanced for the $\mathrm{N}$ amount first, and then balanced with commercial fertilizer to apply $150 \mathrm{~kg} / \mathrm{ha}$ of $\mathrm{P}$ as superphosphate, and $150 \mathrm{~kg} / \mathrm{ha}$ of $\mathrm{K}$ as potassium chloride. Therefore, $3 \mathrm{Mg} \mathrm{HDCGM} / \mathrm{ha}$ and $4.2 \mathrm{Mg}$ $\mathrm{POTL} / \mathrm{ha}$ were applied. The $\mathrm{N}$ source of the commercial fertilizer was urea.

"Prine" annual ryegrass (Lolium multiflorum Lam.) was planted as a cool-season annual forage on December 3, 2010 and October 24, 2011, at a seeding rate of $34 \mathrm{~kg} / \mathrm{ha}$. After three harvests of annual ryegrass, 'Greentreat' sorghum-sudangrass (SS) hybrid (Sorghum bicolor (L.) Moench) was planted on the same plots in a double cropping approach at a $15 \mathrm{~kg}$ /ha seeding rate on May 26, 2011 and May 18, 2012. Same procedures were used to apply fertilizer treatments and seed forage crops for the both cool-season annual forage crops in both years. Thus grasses were established four times on the same site using the same practices, with individual plots receiving four applications of each treatment during the two years. Weather data were collected from the LSU AgCenter weather station at the Southeast Research Station.

\subsection{Bioassay of HDCGM, CGM, and POTL for Degradability}

Quadruplicate 0.50 -g samples of HDCGM and feed grade CGM were weighed and incubated using the in vitro fermentation gas analysis technique (Goering \& Van Soest, 1970), as a bioassay of their biological degradation potential. Samples were incubated at $39{ }^{\circ} \mathrm{C}$ in rumen fluid obtained from a cannulated Holstein cow (Bos taurus) and buffer solution. Fermentation gas production from each incubation bottle was recorded at 30-minute intervals using an Ankom Gas Module (Ankom Technology, Macedon, NY). Four runs of gas measurements with variation less than $\pm 5 \%$ at $65 \mathrm{hr}$ of incubation were used for the analysis. Data fitting a non-linear model were analyzed using Proc NLIN of SAS (SAS Institute, 2013), which was developed by Dr. P. J. Weimer (personal communication). Rate and extent of fermentation gas production were determined for each sample by fitting the gas production data to the single pool logistic model, modified from Schofield, Pitt, and Pell (1994):

$$
V=V_{\mathrm{F}} \cdot\left\{1+\exp \left[2+4 \mu_{\mathrm{m}} / V_{\mathrm{F}} \times(\lambda-t)\right]\right\}^{-1}
$$

where, $V$ is the amount of gas production at time $t, V_{\mathrm{F}}$ is the final gas production volume corresponding to complete substrate digestion for a fermenting pool, $\mu_{\mathrm{m}}$ is the point of inflection of the gas curve, and $\lambda$ is the lag time, respectively.

Residual N content dynamics of HDCGM and POTL were measured in soil using a filter bag technique. Quadruplicate 0.50-g samples of HDCGM and POTL were weighed into F57 filter bags (Ankom Technology, Macedon, NY) and buried in the control plot at a depth of $12 \mathrm{~cm}$ on the same day when fertilizer treatments were 
incorporated. The buried filter bags were recovered at days 3, 6, 9, 12, 24, 48, 72, and 96. Recovered filter bag samples were stored in the lab freezer and processed along with the forage DM samples.

\subsection{Crop Harvest and Sub-sampling}

Three harvests were made during each growing season of two years. The first harvest of annual ryegrass was made in early-March and that of the SS hybrid was made in mid-June each year. The harvest intervals were approximately 45 to 55 days between the harvests. A $0.6-$ by $7.0-\mathrm{m}$ strip of annual ryegrass was cut with a sickle bar mower (Troy-Bilt ${ }^{\circledR}$ Valley City, OH) from the center of each plot at a 5- to 7-cm stubble height. Two 7.0-m long center rows of SS hybrid were harvested using a hand sickle at a $15-\mathrm{cm}$ stubble height. Fresh forage weights were recorded, grab samples were collected for DM production and herbage was removed from the plot. Afterward, the whole plot area was mowed at the same cutting height as the harvested strip. Forage samples of approximately $300 \mathrm{~g}$ from the fresh forage of each plot were dried at $55{ }^{\circ} \mathrm{C}$ for $72 \mathrm{hr}$ to determine DM production and saved for $\mathrm{N}$ analysis.

\subsection{Analysis of HDCGM, POTL and Forage Samples}

Sub-samples of HDCGM and POTL were dried in the same method with the forage samples. Dried HDCGM, POTL, and forage samples were ground to pass a 2-mm screen using a Wiley mill (Arthur H. Thomas Company, Philadelphia, PA), and then ground to pass a 1-mm screen using a Cyclotec 1093 mill (Foss in North America, MN). Mineral concentration in HDCGM and POTL was determined by flame atomic absorption spectrophotometry (Perkin-Elmer Analyst 300, Norwalk, CT) after dry ashing at $500{ }^{\circ} \mathrm{C}$ overnight in porcelain crucibles. Ground forage samples were analyzed for Kjeldahl $\mathrm{N}$ in an automated colorimetric assay adapted for a flow-injection analyzer (QuickChem 8000 FIA, Lachat Instruments, Milwaukee, WI) according to AOAC (1990) procedures. Acid detergent insoluble nitrogen (ADIN) in dried HDCGM samples was determined with acid detergent fiber (ADF) as an intermediate step (Goering \& Van Soest, 1970) using Kieldahl N procedure.

\subsection{Soil Sampling and Soil Analysis}

Three soil samples were collected per plot, using a 2-cm diameter soil sampling tube to a depth of $15 \mathrm{~cm}$, the day before planting annual ryegrass (initial soil sampling) in 2010, and after SS forage harvest on Oct 18, 2012 (final soil sampling). Soil $\mathrm{pH}$ and macro minerals were determined according to Wang, Harrell, Henderson, and Bell (2004). Soil $\mathrm{pH}$ was measured from mixtures of 1:1 soil to water ratio (weight basis). Soil $\mathrm{P}$ was analyzed using Bray $2\left(0.03 \mathrm{M} \mathrm{HH}_{4} \mathrm{~F}+0.1 \mathrm{M} \mathrm{HC}\right)$ with a 1:20 soil to solution ratio (weight basis). Soil $\mathrm{K}, \mathrm{Ca}$, and $\mathrm{Mg}$ were extracted with $1 \mathrm{M} \mathrm{NH}_{4} \mathrm{AO}_{\mathrm{C}}$ using a 1:10 soil to solution ratio and then extracted with Mehlich 3 extractant (Mehlich, 1984) using a soil to solution ratio of 1:10. All elements in extracts were determined using ICP (Ciros model, Spectro Analyticsl Instruments, Inc., Fitchburg, MA 01420). Soil organic matter (SOM) was determined according to Nelson and Sommers (1996).

\subsection{Statistical Analysis}

Residual N of HDCGM and POTL in soil were subject to a repeated measures analysis. Due to the unequal intervals of filter bag recovery from the soil, compound symmetric structure of covariance analysis was applied for modeling of $\mathrm{N}$. Coefficients of linear and quadratic functions were compared for the fixed effects (fertilizer treatment and forage type).

Data (DM production, $\mathrm{N}$ concentration, $\mathrm{N}$ production, and soil characteristics) were analyzed using the Proc Glimmix of SAS version 9.4 (SAS Institute, 2013). Comparisons of the treatment means of forage N concentration, DM production, and $\mathrm{N}$ production were conducted by forage type (cool-season vs warm-season annual grasses), and year of cultivation. Harvests nested within each crop cycle were considered random effect. Pairwise comparisons of least square means of crop responses were conducted considering fertilizer treatment, forage type, year, and interactions of the independent variables as fixed effects to assess possible carryover effects of fertilizers from the first year application to the next year.

\section{Results}

\subsection{Weather and Soil Temperature}

Air temperature and soil temperature demonstrated a similar monthly pattern during two years of cool-season and warm-season annual grass cultivation (Figure 1). Soil temperature remained higher than air temperature approximately by 2 to $5{ }^{\circ} \mathrm{C}$. Rainfall during the fall to spring period (Oct., 2010-Mar., 2011) was more variable in the first year but generally similar to than that in the second year. In contrast, rainfall in April, May, and August in the first year was much lower than that in the second year. 


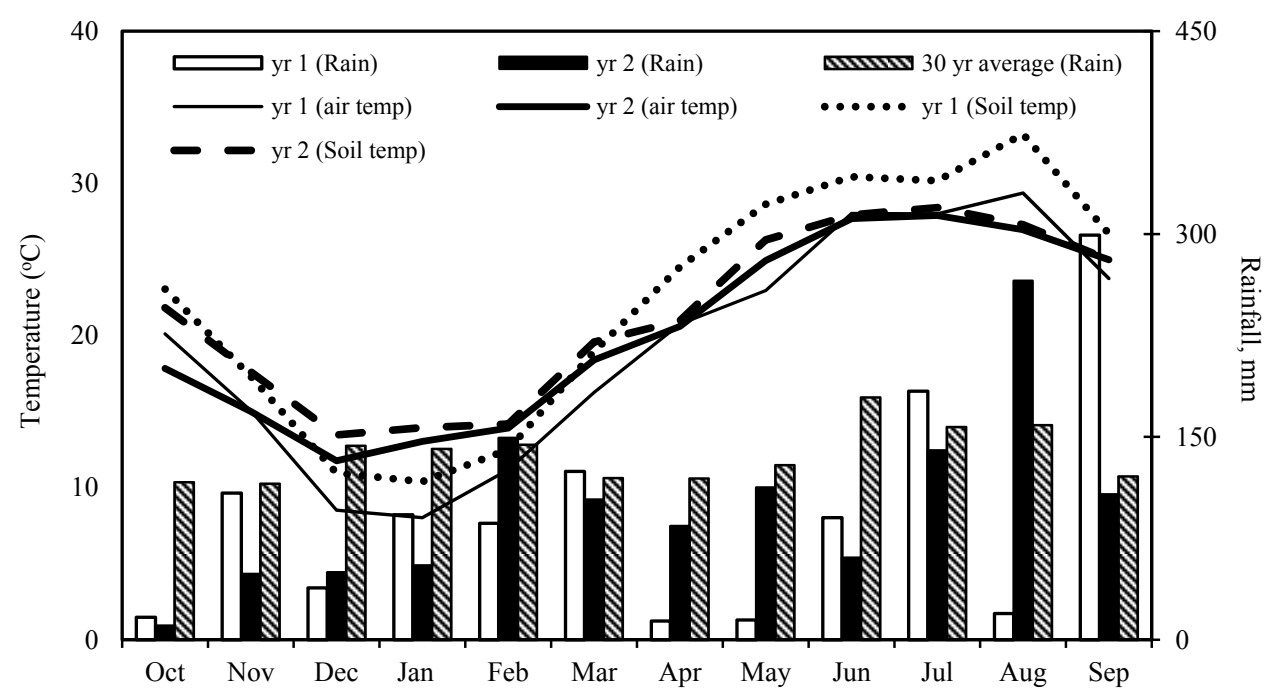

Figure 1. Monthly rainfall, air temperature, and soil temperature of yr 1 (from October 2010 to September 2011) and 2 (from October 2011 to September 2012) with $30 \mathrm{yr}$ monthly rainfall average

\subsection{Characteristics of CGM, HDCGM and POTL}

The nutrient analysis results presented in Table 1 indicate OM comprised more than $850 \mathrm{~g} / \mathrm{kg}$ DM of both POTL and HDCGM. The HDCGM had higher total N than that in POTL (by $25 \mathrm{~g} / \mathrm{kg} \mathrm{DM}$ ), while the P, K, Mg, and Ca contents were much lower than those in POTL. Due to the high $\mathrm{N}$ concentration in HDCGM, C/N ratio of HDCGM was 6.1 units lower than that of POTL.

Comparison of the ruminal fermentation kinetics of HDCGM and feed grade CGM, using an in vitro incubation technique, indicated much reduced degradation of HDCGM under rumen microbial fermentation (Figure 2). Model fitting of fermentation gas curves obtained from in vitro ruminal incubation identified distinct difference between HDCGM and feed grade CGM. The in vitro ruminal fermentation parameters such as fermentation pool size, fermentation rate, and fermentation lag time of HDCGM differed from those of feed grade CGM.

Table 1. Chemical concentrations in POTL (poultry litter) and HDCGM (recycled corn gluten meal)

\begin{tabular}{lll}
\hline Nutrient & POTL & HDCGM \\
\hline Moisture, $\mathrm{g} \mathrm{kg}^{-1}$ & 132 & 229 \\
$\mathrm{OM}, \mathrm{g} \mathrm{kg}^{-1}$ & 876 & 950 \\
Total N, g kg & \\
$\mathrm{C}: \mathrm{N} \mathrm{ratio}$ & 36.5 & 61.8 \\
$\mathrm{Ca}, \mathrm{g} \mathrm{kg}^{-1} \mathrm{DM}$ & 15.9 & 9.8 \\
$\mathrm{P}, \mathrm{g} \mathrm{kg}^{-1} \mathrm{DM}$ & 35.6 & 0.7 \\
$\mathrm{~K}, \mathrm{~g} \mathrm{~kg}^{-1} \mathrm{DM}$ & 25.3 & 11.5 \\
$\mathrm{Mg}, \mathrm{g} \mathrm{kg}^{-1} \mathrm{DM}$ & 38.8 & 16.2 \\
$\mathrm{Zn}, \mathrm{mg} \mathrm{kg}^{-1} \mathrm{DM}$ & 8.2 & 4.5 \\
\hline
\end{tabular}




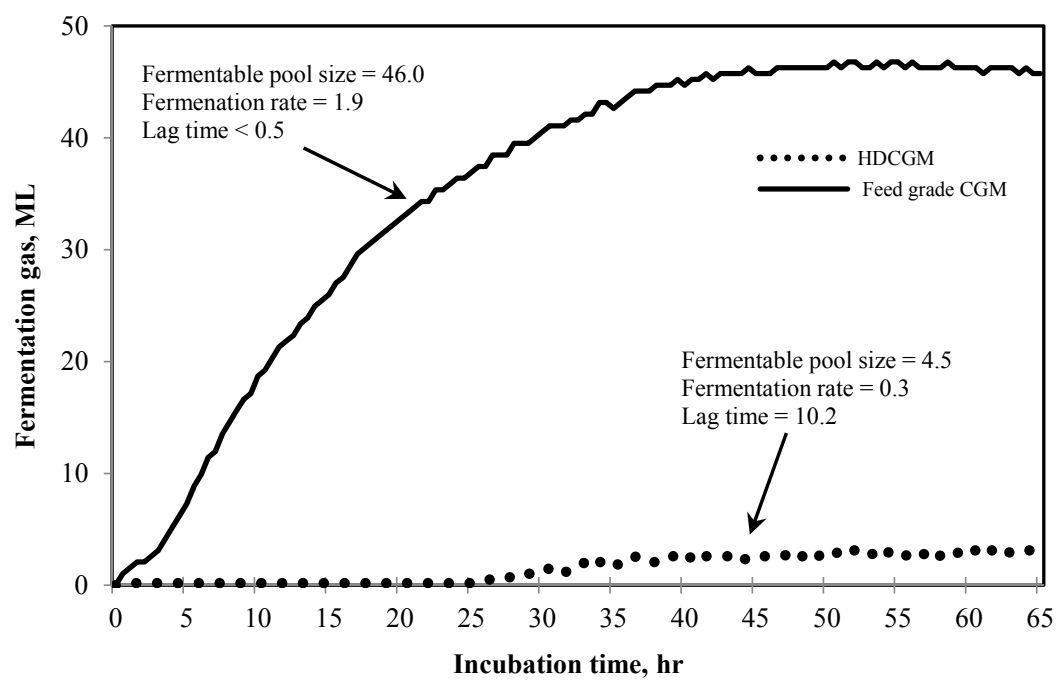

Figure 2. Comparison of the in vitro ruminal fermentation gas accumulation patterns of HDCGM (heat damaged corn gluten meal) and feed grade CGM (corn gluten meal)

The fermentation pool size and fermentation rate of HDCGM were one tenth and one sixth of feed grade CGM, respectively. Fermentation lag time of HDCGM was more than twenty times longer than that of feed grade CGM. The preceding indicates the highly undegradable nature of HDCGM under the ruminal bioassay conditions. Measurement of acid detergent insoluble nitrogen (ADIN) for estimation of the potentially undegradable proportion of nitrogen compounds in HDCGM indicated 93\% of the total $\mathrm{N}$ was in ADIN form (data not presented) and thus highly undegradable.

The residual $\mathrm{N}$ concentration in sequentially recovered HDCGM and POTL filter bag samples, which were buried on the same days as the annual ryegrass or SS hybrid was planted, increased directly with days in soil (Figure 3). The coefficients for the intercept and both linear and quadratic day effect during cool-season and warm-season were all statistically significant (Table 2). The coefficients of linear function of day were positive but the coefficients for quadratic function of day were negative.

Table 2. Linear and quadratic coefficients of recovery day for residual $\mathrm{N}$ concentration in HDCGM (heat damaged corn gluten meal) and POTL (poultry litter) samples buried at the time of planting cool-season and warm-season annual forage grasses

\begin{tabular}{llllll}
\hline \multirow{2}{*}{ Solution Coefficient } & \multicolumn{2}{c}{ Cool-season } & & \multicolumn{2}{c}{ Warm-season } \\
\cline { 2 - 3 } \cline { 5 - 6 } & POTL & HDCGM & & POTL & HDCGM \\
\hline Intercept & 3.22 & 5.95 & 3.31 & 5.94 \\
$P$-value & $<0.0001$ & $<0.0001$ & & $<0.0001$ & $<0.0001$ \\
\hline Day & 0.013 & 0.013 & 0.010 & 0.007 \\
$P$-value & $<0.0001$ & $<0.0001$ & & $<0.0001$ & 0.002 \\
\hdashline Day & -0.00005 & -0.00005 & -0.00004 & -0.00004 \\
$P$-value & 0.0006 & $<0.0001$ & & 0.0043 & 0.0069 \\
\hline
\end{tabular}

Note. ${ }^{2}$, fixed effect of repeated measure analysis with HDCGM and POTL samples recovered at $0,3,6,9,12,24$, 48,72 , and 96 day from soil, averaged for the two year, during the winter growing season and summer growing season.

Based on the estimates of the coefficients of the solutions, model equations for the residual $\mathrm{N}$ content in HDCGM were $5.95+0.0133 \times$ day $-0.00005 \times$ day $^{2}$ during the winter growing season, and $5.94+0.0071 \times$ day $-0.00004 \times$ day $^{2}$ during the warm-season grass growing season. The intercepts were smaller for the POTL than HDCGM for both cool and warm growing seasons, indicating lower initial $\mathrm{N}$ concentration in POTL. The linear day function for HDCGM was the same as of POTL during the winter growing season, while the slopes of linear function for HDCGM were smaller than POTL during the summer growing season. The linear and quadratic day 
coefficients of HDCGM and POTL during the summer growing season were smaller than those during the winter growing season.

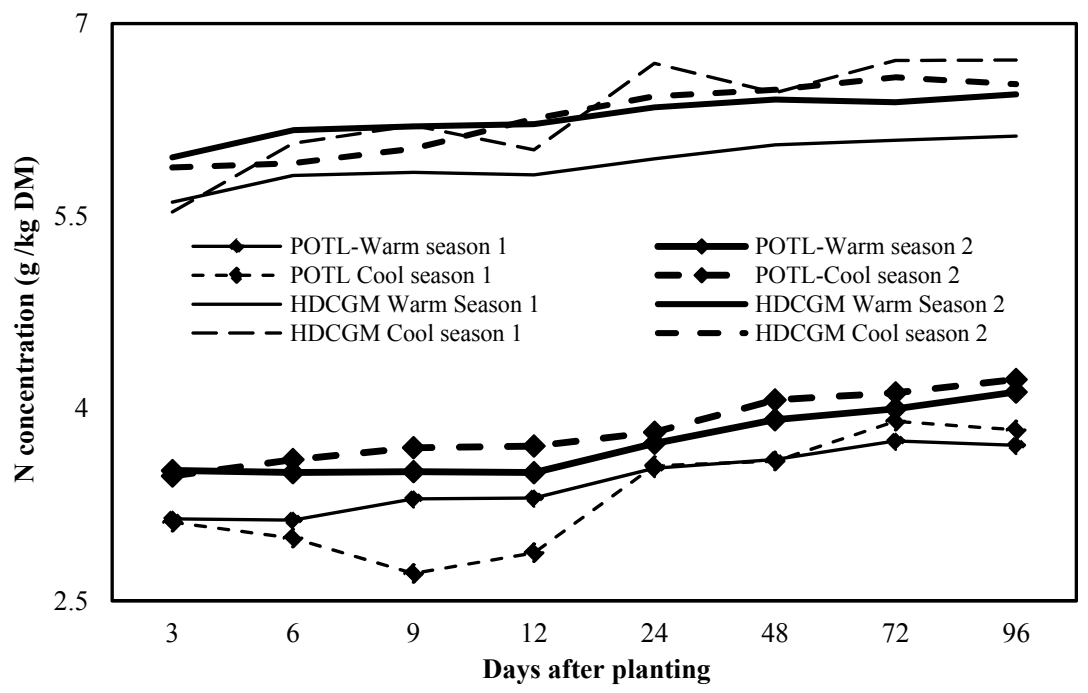

Figure 3. Mean total N content in recovered HDCGM and POTL samples, during the cool and warm seasons

\subsection{Impact on $N$ Concentration, Dry Matter Production and $N$ Yield of Forages}

The fertilizer $\times$ forage type data showed that the HDCGM, POTL and COMF consistently tended to increase (not always significantly) $\mathrm{N}$ concentration, DM production and $\mathrm{N}$ production of forages when compared to ZERO (Table 3). Significant increases over the ZERO were observed only for the SS hybrid DM production by POTL, for the ryegrass DM production by COMF, and for the ryegrass N production by POTL and COMF. Regardless of fertilizer treatment, annual ryegrass produced forage containing higher N concentration than the SS hybrid, but its DM production was less than SS hybrid. The means of forage $\mathrm{N}$ concentration, DM production, and $\mathrm{N}$ production did not show significant differences between the HDCGM, POTL and COMF treatments, except for greater $\mathrm{N}$ production from ryegrass with POTL than HDCGM. Since N production of forage receiving the different fertilizer treatments was estimated by the function of forage production and $\mathrm{N}$ concentration, $\mathrm{N}$ production demonstrated a different pattern from the forage production. The mean $\mathrm{N}$ production of annual ryegrass receiving HDCGM was lower than that of annual ryegrass receiving POTL. The $\mathrm{N}$ production from HDCGM was equivalent to that of the SS hybrid receiving COMF.

Fertilizer $\times$ year of cultivation data indicated that $\mathrm{N}$ concentration tended to be higher in the first than second year, but did not differ significantly within each fertilizer treatment, except for the ZERO treatment (Table 3). Forage DM production was significantly lower in the first year than second year for the HDCGM, POTL, and COMF, indicating nutrients carry over from the first to second year. Also the DM production was not significantly influenced by fertilizer treatments in the first year, while it was significantly greater with the HDCGM, POTL, and COMF than ZERO in the second year. The N production of the first year was lower than the second year for the POTL and COMF. Similar to the DM production, the N production did not show significant effect of the fertilizer treatments in the first year, while it was significantly greater with the HDCGM, POTL and COMF than ZERO in the second year.

Forage type $\times$ year mean of $\mathrm{N}$ concentration indicated annual ryegrass contained higher $\mathrm{N}$ than the SS hybrid, and $\mathrm{N}$ concentration in annual ryegrass in the first year was higher than in the second year (Table 3 ). Forage DM production of annual ryegrass did not differ between the years of cultivation, while the SS hybrid produced much more forage in the second than first year. The N production was similar for the second-year SS hybrid and the first-year annual ryegrass with less N production by the second-year annual ryegrass. The first-year SS hybrid produced the least amount of $\mathrm{N}$ compared to its second year and also ryegrass in both years. 
Table 3. Averages from three harvests of SS (sorghum sudangrass) hybrid and annual ryegrass for nitrogen (N) concentration, forage dry matter (DM) production, and $\mathrm{N}$ production, presented as interactions of fertilizer treatment $\times$ forage type, fertilizer treatment $\times$ cultivation year, and forage type $\times$ cultivation year

\begin{tabular}{|c|c|c|c|c|}
\hline & & $\begin{array}{l}\text { N concentration } \\
(\mathrm{g} / \mathrm{kg} \mathrm{DM})\end{array}$ & $\begin{array}{l}\text { Forage DM yield } \\
(\mathrm{kg} / \mathrm{ha})\end{array}$ & $\begin{array}{l}\text { N yield } \\
\text { (kg/ha) }\end{array}$ \\
\hline Fertilizer Treatment $\dagger$ & Forage type & \multicolumn{3}{|c|}{ Fertilizer $\times$ forage type } \\
\hline \multirow[t]{2}{*}{ ZERO } & SS hybrid & $15.4 \mathrm{~b} \ddagger$ & $2828 b c$ & $40.3 \mathrm{c}$ \\
\hline & Annual ryegrass & $26.2 \mathrm{a}$ & $1988 \mathrm{c}$ & $49.6 \mathrm{bc}$ \\
\hline \multirow[t]{2}{*}{ HDCGM } & SS hybrid & $17.2 \mathrm{~b}$ & $3961 \mathrm{ab}$ & $61.0 \mathrm{bc}$ \\
\hline & Annual ryegrass & $26.8 \mathrm{a}$ & $2537 \mathrm{bc}$ & $65.6 \mathrm{bc}$ \\
\hline \multirow[t]{2}{*}{ POTL } & SS hybrid & $17.7 \mathrm{~b}$ & $4518 \mathrm{a}$ & $68.3 \mathrm{abc}$ \\
\hline & Annual ryegrass & $30.2 \mathrm{a}$ & $3370 \mathrm{abc}$ & $94.7 \mathrm{a}$ \\
\hline \multirow[t]{2}{*}{ COMF } & SS hybrid & $16.1 \mathrm{~b}$ & $3455 \mathrm{ab}$ & $54.5 \mathrm{bc}$ \\
\hline & Annual ryegrass & $27.7 \mathrm{a}$ & $2920 b c$ & $71.4 \mathrm{ab}$ \\
\hline Fertilizer Treatment & Year of cultivation & \multicolumn{3}{|l|}{ Fertilizer $\times$ year } \\
\hline \multirow[t]{2}{*}{ ZERO } & 1 & $23.4 \mathrm{ab}$ & $1789 \mathrm{~b}$ & $45.1 \mathrm{~d}$ \\
\hline & 2 & $18.1 \mathrm{c}$ & $3027 b$ & $44.8 \mathrm{~d}$ \\
\hline \multirow[t]{2}{*}{ HDCGM } & 1 & $24.3 \mathrm{ab}$ & $1923 b$ & $51.8 \mathrm{~cd}$ \\
\hline & 2 & $19.8 \mathrm{bc}$ & $4575 \mathrm{a}$ & $74.8 \mathrm{abc}$ \\
\hline \multirow[t]{2}{*}{ POTL } & 1 & $25.9 \mathrm{a}$ & $2380 \mathrm{~b}$ & $66.8 \mathrm{bcd}$ \\
\hline & 2 & $22.0 \mathrm{abc}$ & $5508 \mathrm{a}$ & $96.2 \mathrm{a}$ \\
\hline \multirow[t]{2}{*}{ COMF } & 1 & $22.2 \mathrm{abc}$ & $1739 \mathrm{~b}$ & $43.9 \mathrm{~d}$ \\
\hline & 2 & $21.7 \mathrm{abc}$ & $4636 a$ & $81.9 \mathrm{ab}$ \\
\hline Forage type & Year of cultivation & \multicolumn{3}{|c|}{ Forage type $\times$ year } \\
\hline \multirow[t]{2}{*}{ SS hybrid } & 1 & $16.0 \mathrm{c}$ & $1503 \mathrm{c}$ & $21.4 \mathrm{c}$ \\
\hline & 2 & $17.1 \mathrm{c}$ & $5878 \mathrm{a}$ & $90.6 \mathrm{a}$ \\
\hline \multirow[t]{2}{*}{ Annual ryegrass } & 1 & $31.8 \mathrm{a}$ & $2412 b$ & $82.4 \mathrm{a}$ \\
\hline & 2 & $23.7 b$ & $2995 b$ & $58.3 \mathrm{~b}$ \\
\hline
\end{tabular}

Note. $\dagger$, HDCGM, heat damaged corn gluten meal; POTL, poultry litter; COMF, commercial fertilizer; and ZERO, no fertilization.

$\ddagger$, Mean values followed by the same letter or letters within the same column and interaction $\operatorname{did}$ not $\operatorname{differ}$ at $P>$ 0.05 .

\subsection{Soil Chemical Properties}

The SOM remained at a similar level between before annual grass cultivation and after four treatment applications (Table 4). However, the final SOM level after the HDCGM treatment was higher than that in the ZERO and COMF treatments. Soil N content after the HDCGM was higher than that of other three treatments and was the only treatment to maintain near the initial soil $\mathrm{N}$ level after two years of grass cultivation and treatment application.

After two years of annual grass cultivation, soil $\mathrm{pH}$ and $\mathrm{Mg}$ content for the two organic fertilizer treatments, POTL and HDCGM, were significantly greater than the ZERO and COMF treatments, and also increased from the initial $\mathrm{pH}$ and $\mathrm{Mg}$ content measured before the annual grass cultivation (Table 4). In contrast to increased soil $\mathrm{pH}$ and $\mathrm{Mg}$ with the organic soil amendments, the concentrations of $\mathrm{P}, \mathrm{K}$, and $\mathrm{S}$ in all treatments declined after two years of cultivation. 
Table 4. Soil characteristics before cultivation and after two years of forage crop cultivation including four applications of treatments, averaged by treatment (ZERO, zero fertilization; COMF, commercial fertilizer; POTL, poultry litter; HDCGM, heat damaged corn gluten meal)

\begin{tabular}{llllll}
\hline \multirow{2}{*}{ Soil characteristics } & Before cultivation $\dagger$ & \multicolumn{3}{c}{ After cultivation with fertilizer treatment } \\
\cline { 3 - 5 } & & ZERO & COMF & POTL & HDCGM \\
\hline Organic matter, g/kg & 34.1 & $32.0 \mathrm{~b} \dagger$ & $31.1 \mathrm{~b}$ & $33.7 \mathrm{ab}$ & $37.1 \mathrm{a}$ \\
Nitrogen, g/kg & 1.59 & $0.91 \mathrm{~b}$ & $0.82 \mathrm{~b}$ & $0.88 \mathrm{~b}$ & $1.46 \mathrm{a}$ \\
$\mathrm{pH}(1: 1 \mathrm{Water})$ & 5.9 & $5.9 \mathrm{~b}$ & $5.9 \mathrm{~b}$ & $6.2 \mathrm{a}$ & $6.2 \mathrm{a}$ \\
$\mathrm{P}, \mathrm{mg} \mathrm{kg}^{-1}$ & 44.2 & $20.1 \mathrm{c}$ & $31 \mathrm{~b}$ & $38.4 \mathrm{a}$ & $26.7 \mathrm{~b}$ \\
$\mathrm{~K}, \mathrm{mg} \mathrm{kg}^{-1}$ & 66.2 & $40.4 \mathrm{~b}$ & $55 \mathrm{a}$ & $47 \mathrm{ab}$ & $55.5 \mathrm{a}$ \\
$\mathrm{S}, \mathrm{mg} \mathrm{kg}^{-1}$ & 13.5 & $9.5 \mathrm{a}$ & $8.8 \mathrm{~b}$ & $9.9 \mathrm{a}$ & $9.2 \mathrm{a}$ \\
$\mathrm{Mg}, \mathrm{mg} \mathrm{kg}^{-1}$ & 199.5 & $189.1 \mathrm{~b}$ & $192.2 \mathrm{~b}$ & $261.1 \mathrm{a}$ & $250.6 \mathrm{a}$ \\
$\mathrm{Zn}, \mathrm{mg} \mathrm{kg}^{-1}$ & 1.5 & $1.0 \mathrm{a}$ & $0.9 \mathrm{a}$ & $2.0 \mathrm{a}$ & $1.2 \mathrm{a}$ \\
\hline
\end{tabular}

Note. $\dagger$, Soil characteristics of before cultivation were measure with the random samples of whole plot area.

$\$$, Numbers within a row followed by the same letter(s) did not differ at $P<0.05$.

Due to high $\mathrm{P}$ concentration in the POTL, soil P level after grass cultivation was significantly higher with POTL than other treatments, and it was also near the initial P level. Compared with COMF, the S and Mg in soils receiving POTL and HDCGM were higher after the two years of treatment.

\section{Discussion}

Release of $\mathrm{N}$ from organic materials such as HDCGM and POTL is a function of soil microorganisms, soil moisture, aeration, and soil temperature (Sistani, Adeli, McGowen, Tewolde, \& Brink, 2008). The differences in forage DM production and N production between HDCGM and POTL during cool-season probably reflect differences in their $\mathrm{N}$ mineralization rates under low temperatures. Similar forage production for the two treatments during the warm season indicates that the labile pool of $\mathrm{N}$ in soil treated with HDCGM increased to a similar level to that of the POTL and COMF treatments, perhaps due to a combination of the warmer soil temperature in summer and the accumulated $\mathrm{N}$ from the combined spring and fall applications of HDCGM. Such a summer temperature benefit agrees with Adair et al. (2008) who reported improved performance of SOM decomposition models based on first order kinetics with increasing soil moisture and temperature. Such a temperature effect can even occur with unusually warm winter weather (Lehrsch, Brown, Lentz, Johnson-Maynard, \& Leytem, 2016).

Although more rapid mineralization of HDCGM and POTL was expected in the summer soil environment than during the winter due to high soil temperature and perhaps periodically higher soil moisture, the residual $\mathrm{N}$ dynamics did not reflect the seasonal DM production difference. Samples of HDCGM and POTL buried in filter bags indicated similar $\mathrm{N}$ dynamics during the two seasons (Figure 3 and Table 2). The filter bag samples buried at the 12-cm depth in soil during the summer growing season were probably in drier soil conditions than those in the winter growing season, due to low precipitation and high evaporation rate of soil moisture under the hot and dry summer weather. Especially in the summer growing season of the first year (between April and June 2011), southeastern LA received much less rainfall than the 30 year long-term average (Figure 1). In contrast to the summer growing season, mild winter weather and less evaporation rate of soil moisture may have provided a more suitable environment for decomposition of SOM at $12 \mathrm{~cm}$ soil depth. However, modeling mineralization of $\mathrm{N}$ with soil temperature and soil moisture is more challenging than for soil C. Leiros, Trasar-Cepeda, and Seoane (1999) reported difference of model performance between evolvement for $\mathrm{N}$ and C. Their attempt could only explain around $30 \%$ of variance for $\mathrm{N}$, while the same attempt for evolvement of C could explain $80 \%$ of the variance. This difference in model performance between $\mathrm{N}$ and $\mathrm{C}$ was explained with a relatively complicated $\mathrm{N}$ cycle in soils and involvement of specific soil microbes in $\mathrm{N}$ mineralization (Leiros et al., 1999). There would also be interaction between existing SOM and added OM from the HDCGM and POTL. Complexity of N mineralization from organic soil amendments with multiple interacting effects and the need for additional research to allow estimation of net $\mathrm{N}$ mineralization responses has been assessed by Cabrera, Kissel, and Vigil (2005). In the summer growing season, residue of cool-season grass in the soil may have been more readily degraded because of the relatively low $\mathrm{C}-\mathrm{N}$ ratio for the forage from annual ryegrass (due to higher $\mathrm{N}$ concentration) compared to that of the warm-season SS hybrid, as indicated by their $\mathrm{N}$ concentrations presented 
in Table 3. With a high-N soybean residue, approximately $26 \%$ of incorporated $\mathrm{N}$ from the soybean residue was recovered by a following crop (Norman \& Werkman, 1943).

Coefficients of quadratic function of day for the residual $\mathrm{N}$ concentration were all negative and significant for both POTL and HDCGM during both the winter and summer growing seasons (Table 2), because the residual N concentration in the sequentially recovered filter bag samples increased in a linear pattern. However, with subsequent days in soil, the $\mathrm{N}$ concentration increased at a lower rate (Figure 3). Even with the higher $\mathrm{N}$ concentration (Table 1) and lower C-N ratio of HDCGM than that of POTL, because of its high proportion of bound $\mathrm{N}$, the $\mathrm{N}$ release from the HDCGM would not be expected to be as fast as that in POTL. However, the coefficients of day function during cool season were same for the HDCGM and POTL, while POTL had higher coefficient of day than HDCGM during warm season (Table 2). Differences in N release from HDCGM and POTL during warm season were similar to those found between composted and non-composted poultry litter (Preusch, Adler, Sikora, \& Tworkoski, 2002). The bound N in HDCGM should be highly resistant to microbial degradation in soil as demonstrated by the in vitro fermentation analysis in this study (Figure 2). The lower ruminal degradation of HDCGM than that of feed grade CGM indicates recalcitrance of HDCGM. Bound N in HDCGM as quantified using ADIN analysis (Licitra, Hernandez, \& Van Soest, 1996) averaged around 86\% in this study (data not presented). This high proportion of ADIN in the total $\mathrm{N}$ apparently contributed to the slower and reduced contribution of HDCGM to forage production compared to POTL, and also contributed to higher $\mathrm{OM}$ and $\mathrm{N}$ in the soil after 2 years (Table 4).

Since the three harvests in each growing season were nested in year and considered as a random effect in the statistical analysis of these data, the forage DM production by harvest number are presented as an appendix. The three cool-season harvests presented a different forage DM production pattern for COMF and POTL than those of HDCGM. The COMF and POTL treatments demonstrated a sharp increase of forage production at the second harvest among the three harvests and then sharp reduction to the third harvest (Appendix A), while HDCGM produced more uniformly distributed DM production throughout the growing season. Kowaljow, Mazzarino, Satti, and Jimenez-Rodriquez (2010) reported that application of inorganic fertilizer increased DM production primarily through an initial pulse of available $\mathrm{N}$, while organic fertilizers should have more positive sustained impact on soil chemical and biological properties. This is supported by the much slower $\mathrm{N}$ release from HDCGM and perhaps POTL than that of COMF. Overall, the two organic fertilizer treatments in this study, POTL and HDCGM, produced linearly increasing forage DM production throughout the three cool-season harvests, while COMF produced the most forage in the second harvest, indicating a fast and early peak of the available $\mathrm{N}$ pool in the soil following application of COMF.

Forage DM production in the second year was greater by 69 to $167 \%$ than in the first year (Table 3 ). The largest increase in forage production was with COMF (167\%), while the increase with HDCGM and POTL was around $135 \%$ and with ZERO control by $69 \%$. Thus, forage production indicated more favorable growing conditions in second than first year. The second-year DM production demonstrated advantage of the $\mathrm{N}$ credit from the applied $\mathrm{N}$ in first year, as indicated by larger DM production increase in second year over first year by the HDCGM, POTL and COMF treatments than the ZERO, which would not be expected from the often volatile urea in the commercial fertilizer. Similar pattern was also shown by the $\mathrm{N}$ production data. Slower release of $\mathrm{N}$ from the organic materials is expected to provide potential for greater second-year benefits from the HDCGM and POTL as N sources than from COMF. This was not, however, the result obtained. Earlier, Gill (2019) observed N from urea was carried over to benefit crop in next year, when the growing season was dry and higher than recommended $\mathrm{N}$ rate was applied. Our results are consistent with those of Lehrsch, Brown, Lentz, Johnson-Maynard, and Leytem (2017) who demonstrated such second-year N benefits from organic N sources only when the amount of $\mathrm{N}$ applied exceeded the $\mathrm{N}$ demand of the crop grown in the initial year. Higher SOM levels after two years of HDCGM and POTL than COMF and ZERO indicate that some of the $\mathrm{N}$ from the applied HDCGM and POTL was not mineralized during the two years, and may benefit crops in following years.

Although cool-season forage DM production was less than that during the warm season, the high $\mathrm{N}$ concentration of the cool-season forage (ryegrass mean $\mathrm{N}$ concentration $=27.7 \mathrm{~g} / \mathrm{kg} \mathrm{DM}$ ) resulted in greater N production than the warm-season forage (SS hybrid mean $\mathrm{N}$ concentration $=16.6 \mathrm{~g} / \mathrm{kg} \mathrm{DM}$ ) (Table 3). The difference in $\mathrm{N}$ production between the 2 years was mostly a function of increased forage production in the second year, despite lower $\mathrm{N}$ concentration in forage.

\section{Conclusions}

With higher $\mathrm{N}$ concentration than poultry litter, HDCGM has value as an alternative organic fertilizer producing an amount of annual grass DM comparable to that of a commercial fertilizer with more uniform forage 
distribution. The highly bound $\mathrm{N}$ in HDCGM was not as effective as that of POTL to boost annual forage crop production during the cool season. However, HDCGM was as effective as POTL for warm-season grass production. The season of use should therefore be a consideration with HDCGM application as a source of N. Application of HDCGM is less likely to result in $\mathrm{N}$ leaching than commercial fertilizer sources and also contributes to increased soil $\mathrm{N}$ and SOM without a substantial negative impact on establishment of cool-season or warm-season annual forage grasses.

\section{References}

Adair, E. C., Parton, W. J., Del Grosso, S. J., Silver, W. L., Harmon, M. E., Hall, S. A., ... Hart, S. C. (2008). Simple three pool kinetic model describes patterns of long-term litter decomposition in diverse climates. Global Change Biology, 14, 2636-2660. https://doi.org/10.1111/j.1365-2486.2008.01674.x

AOAC (Association of Official Analytical Chemists). (1990). Official Methods of Analysis (15th ed.). Arlington, VA: Association of Official Analytical Chemists.

Cabrera, M. L., Kissel, D. E., \& Vigil, M. F. (2005). Nitrogen mineralization from organic residues: Research opportunities. Journal of Environmental Quality, 34, 75-79. https://doi.org/10.2134/jeq2005.0075

Chalker-Scott, L. (2019). Cornmeal and corn gluten meal applications in gardens and landscapes (Home garden series, FS326E). Washington State University Extension and the U.S. Dept. of Agric.

Eichhorn, Jr. M. M., Redfearn D. D., \& Venuto, B. C. (2000). Cool-season Forage Crop Production on North Louisiana Coastal Plain Soil: 2. A Summary of Varietal Studies on Annual Ryegrass, Cereal Rye, Tall Fescue, and Bromegrass (Circular No. 138). Baton Rouge, LA: Louisiana State University.

Firkins, J. L., Berger, L. L., Fahey Jr., G. C., \& Merchen, N. R. (1984). Ruminal nitrogen degradability and escape of wet and dry distillers grains and wet and dry corn gluten feeds. Journal of Dairy Science, 67, 1936-1944. https://doi.org/10.3168/jds.S0022-0302(84)81527-1

Gill, K. S. (2019). Responses of residual and recommended N, P, K, S nutrients and crops to six annual soil test-based fertilizer rates and seeding systems. Journal of Plant Nutrition, 42(3), 234-249. https://doi.org/ 10.1080/01904167.2018.1554076

Goering, H. K., \& Van Soest, P. J. (1970). Forage fiber analysis (apparatus, reagents, procedures and some applications). Agricultural Handbook No. 379. Washington, DC: ARS-USDA.

Kowaljow, E., Mazzarino, M. J., Satti, P., \& Jimenez-Rodriquez, C. (2010). Organic and inorganic fertilizer effects on a degraded Pantagonian rangeland. Plant and Soil, 332, 135-145. https://doi.org/10.1007/ s11104-009-0279-4

Lehrsch, G. A., Brown, B., Lentz, R. D., Johnson-Maynard, J. L., \& Leytem, A. B. (2016). Winter and growing season nitrogen mineralization from fall-applied composted and stockpiled solid dairy manure. Nutrient Cycling in Agroecosystems, 104, 125-142. https://doi.org/10.1007/s10705-015-9755-9

Lehrsch, G. A., Brown, B., Lentz, R. D., Johnson-Maynard, J. L., \& Leytem, A. B. (2017). Winter wheat yield, quality, and nitrogen removal following compost- or manure-fertilized sugarbeet. Communications in Soil Science and Plant Analysis, 48, 124-138. https://doi.org/10.1080/00103624.2016.1254233

Leiròs, M. C., Trasar-Cepeda, C., \& Seoane, S. (1999). Dependence of mineralization of soil organic matter on temperature and moisture. Soil Biology and Biochemistry, 31, 327-335. https://doi.org/10.1016/S0038-0717 (98)00129-1

Licitra, G., Hernandez, T. M., \& Van Soest, P. J. (1996). Standardization of procedures for nitrogen fractionation of ruminant feeds. Animal Feed Science and Technology, 57, 347-358. https://doi.org/10.1016/0377-8401 (95)00837-3

Liu, L. D., Christians, N. E., \& Garbutt, J. T. (1994). Herbicidal activity of hydrolyzed corn gluten meal on three grass species under controlled environments. Journal of Plant Growth Regulation, 13, 221-226. https://doi.org/10.1007/BF00226040

McDade, M. C., \& Christians, N. E. (2000). Corn gluten meal a natural pre-emergence herbicide: Effect on vegetable seedling survival and weed cover. American Journal of Alternative Agriculture, 15, 189-191. https://doi.org/10.1017/S0889189300008778

Mehlich, A. (1984). Mehlich 3 soil test extractant: A modification of Mehlich 2 extractant. Communications in Soil Science and Plant Analysis, 15, 1409-1416. https://doi.org/10.1080/00103628409367568 
Nelson, D. W., \& Sommers, L. E. (1996). Total carbon, organic carbon and organic matter. In D. L. Sparks (Ed.), Methods of Soil Analysis Part 3: Chemical Methods (pp. 961-1010, SSSA Book Series 5). Madison, WI: Soil Science Society of America.

Norman, A. G., \& Werkman, C. H. (1943). The use of the nitrogen isotope N15 in determining nitrogen recovery from plant materials decomposition in soil. Agronomy Journal, 35, 1023-1025. https://doi.org/10.2134/ agronj1943.00021962003500120004x

Preusch, P. L., Adler, P. R., Sikora, L. J., \& Tworkoski, T. J. (2002). Nitrogen and phosphorus availability in composted and uncomposted poultry litter. Journal of Environmental Quality, 31, 2051-2057. https://doi.org/10.2134/jeq2002.2051

SAS Institute Inc. (2013). SAS® 9.4 Statements: Reference. Cary, NC: SAS Institute Inc.

Schofield, P., Pitt, R. E., \& Pell, A. N. (1994). Kinetics of fiber digestion from in vitro gas production. Journal of Animal Science, 72, 2980-2991. https://doi.org/10.2527/1994.72112980x

Sistani, K. R., Adeli, A., McGowen, S. L., Tewolde, H., \& Brink, G. E. (2008). Laboratory and field evaluation of broiler litter nitrogen mineralization. Bioresource Technology, 99, 2603-2611. https://doi.org/10.1016/ j.biortech.2007.04.069

Titgemeyer, E. C., Merchen, N. R., \& Berger, L. L. (1989). Evaluation of soybean meal, corn gluten meal, blood meal and fish meal as sources of nitrogen and amino acids disappearing from the small intestine of steers. Journal of Animal Science, 67, 262-275. https://doi.org/10.2527/jas1989.671262x

Van Soest, P. J., \& Mason, V. C. (1991). The influence of the Maillard reaction upon the nutritive value of fibrous feeds. Animal Feed Science and Technology, 32, 45-53. https://doi.org/10.1016/0377-8401 (91)90008-G

Wang, J. J., Harrell, D. L., Henderson, R. E., \& Bell, P. F. (2004). Comparison of soil-test extractants for phosphorus, potassium, calcium, magnesium, sodium, zinc, copper, manganese, and iron in Louisiana soils. Communications in Soil Science and Plant Analysis, 35, 145-160. https://doi.org/10.1081/CSS-120027640

Webber, C. L., Shrefler, J. W., \& Taylor, M. J. (2008). Corn gluten meal as an alternative weed control option for spring transplanted onions. International Journal of Vegetable Science, 13, 17-33. https://doi.org/10.1300/ J512v13n03_03

Wu, Y. V. (2001). Emulsifying activity and emulsion stability of corn gluten meal. Journal of the Science of Food and Agriculture, 81, 1223-1227. https://doi.org/10.1002/jsfa.934

\section{Appendix A}

Averages Forage Dry Matter Production Presented by Harvest Number $\times$ Fertilizer Treatment $\times$ Forage Type

\begin{tabular}{lcccc}
\hline \multirow{2}{*}{ Harvest number } & \multicolumn{4}{c}{ Treatment } \\
\cline { 2 - 5 } & ZERO & COMF & POTL & HDCGM \\
\hline Cool season ryegrass harvests & & & & \\
1 & 1757 & 2150 & 2575 & 2206 \\
2 & 2336 & 4590 & 4975 & 2988 \\
3 & 2133 & 2018 & 2560 & 2417 \\
\hdashline Warm season SS hybrid harvests & 1787 & 2281 & 2119 & 2340 \\
1 & 2189 & 3606 & 4651 & 3614 \\
2 & 4509 & 4478 & 6785 & 5930 \\
3 & & & & \\
\hline
\end{tabular}

\section{Copyrights}

Copyright for this article is retained by the author(s), with first publication rights granted to the journal.

This is an open-access article distributed under the terms and conditions of the Creative Commons Attribution license (http://creativecommons.org/licenses/by/4.0/). 